\title{
Absenteeism study in a steel industry of São José dos Campos, SP, Brazil
}

\author{
Isa Azevedo de Almeida Marote', Dagmar de Paula Queluz² \\ 'UNIODONTO, Private Dental Clinic, São José dos Campos, SP, Brazil \\ 2Universidade de Campinas - UNICAMP, Piracicaba Dental School, Department of Community Dentistry, Piracicaba, SP, Brazil
}

\begin{abstract}
Aim: To identify the factors involved in absenteeism in a steel industry in the city of São Jose dos Campos, São Paulo, Brazil. Methods: A cross-sectional study was carried out after obtaining permission from Institutional Ethics Committee in a steel industry. Worker's detailed information regarding absenteeism was obtained from the Health Department files, from January 2005 to December 2008. Specifical data were: sex, function, certificate type (medical or dental), the working sector, according to the Large Groups (LG) of Brazilian Classification of Occupations - 2002, working periods, duration of absenteeism (lost days), the main causes of absenteeism (International Classification of Diseases ICD-10). Results: A total of 570 workers were recorded. The majority of workers were males (97\%), with medical certificate (97\%), LG-7 workers in the production of industrial goods and services $(62.09 \%)$, and operators of industrial machinery $(68.3 \%)$ and the working period was Shift 4 - Monday to Friday from 8 am to 12 am and $1 \mathrm{pm}$ to $5 \mathrm{pm}$ (44.43\%). The total duration of absenteeism was 3,187 days, the main causes of diseases being problemas in the musculoskeletal system and connective tissue (18.48\%), respiratory diseases $(17.11 \%)$, injuries, poisoning and other external causes (11.24\%), and diseases of the digestive tract (11.24\%). Conclusions: It was concluded that there was under-reporting of absenteeism due to dental causes (41 events) during the study period. More studies in this field are required.
\end{abstract}

Keywords: Absenteeism. Workers. Iron and Steel Industry.

\section{Introduction}

In the early 20th century, the Brazilian steel-making sector had very little economic meaning. However, when the National Steel Company was created in 1941, as an answer to the national steel problem, the domestic steel-making industry was much more significant ${ }^{1}$.

The search for total quality in the 1980s and 1990s has stimulated the competitivity among companies, forcing them to adapt to the market ${ }^{2,3}$.

With the globalization, the industry is under international competition, with stress on important things like technology, efficiency, maximum productivity, zero waste, sustainability, lower cost, better quality and flexibility to pursue the business activity.

Received for publication: June 17, 2016 Accepted: September 09, 2016

Correspondence to: Dagmar de Paula Queluz Faculdade de Odontologia de Piracicaba - UNICAMP Departamento de Odontologia Social Avenida Limeira, 901, CEP: 13414-900

Piracicaba, SP, Brasil Phone: +55 1921065277 E-mail: dagmar@fop.unicamp.br Thus, constant changes in production and marketing, the workers' needs to improve their daily commitment and new updates, stress and diseases caused by the specific work activity, like exposure to heavy metals, acids, high temperatures and toxic products. In addition to stress, it may trigger systemic diseases such as increased blood pressure, heart attacks and other heart problems; failing immune system; depression and gynecological infections in women ${ }^{4}$.

Health is the word for one of the fundamental pillars for the development of a nation. The employee is a key component in the production process of the industry, playing an important role in the economy, so that all results are achieved successfully; therefore, 
providing general health assistance to the individual is necessary ${ }^{5-10}$.

The work "De Morbis Artificium Datriba"11 points out that there is a relationship between health and disease in the Egyptian papyri, which is considered the mark in the history of work diseases, since they describe diseases related to more than 50 occupations ${ }^{11}$.

For Rouquayrol and Almeida Filho ${ }^{12}$ : "the health of the worker can be considered a social practice that is established in the scope of public health, seeking to contribute to the transformation of the workers health and, by extension, of the general population, the way to understand particular work processes, in an articulated way with the consumption of goods and services and the set of values, beliefs, ideas and social representations characteristic of a moment in human history".

According to Höfelmann and Blank ${ }^{13}$, health self-evaluation is an important predictor of morbidity and mortality and most of its effects are influenced by the chronic diseases and/or symptoms.

Absenteeism is a complex phenomenon with a multifactorial etiology including psychosocial, economic and work environment factors, so that it may provide important information about the health status of the population. However, its prevalence and its main causes are still poorly documented. For this reason, it is difficult to develop prevention and rehabilitation programs for this population ${ }^{2,5-7,14,15}$.

In the work environment, oral health is a differential. With a specialist in occupational dentistry, some enterprises stand out by their social commitment, increased quality of life for their employees, also aiming to decrease absenteeism, because in the oral cavity may be located the so-called "occupational diseases" with manifestations in the mucosa and some alterations of enamel. Therefore, it is possible to consider that certain diseases have their initial manifestation in the oral tissues, allowing an early and preventive diagnosis ${ }^{5,16-18}$.

Studies have demonstrated that absenteeism resulting from dental reasons varies from 10 to $35 \%$ of the total amount, and the average number of lost working hours varies from 1.24 to 6.20 working hours/worker/year ${ }^{19}$.

Therefore, it is up to the specialist in occupational dentistry to work with professionals involved in the area of occupational health and safety in the company, according to \#4 Regulatory Norm 9 . $\mathrm{He} / \mathrm{she}$ should be concerned with the social and political analysis of the issue, interacting with the working class and management. Compatibility between the work activity and the preservation of the worker's oral health should be the permanent issue. To identify, evaluate and follow up the environmental factors that may constitute a risk to oral health at work, at any stage of the productive process. Technical advice and attention on safety health, ergonomics and hygiene at work, as well as on personal protective equipment, are included in the multidisciplinary health team of the working persons. Planning and implementation of campaigns and permanent programs is important for the education of workers, regarding work accidents, occupational diseases and health education. To organize morbidity and mortality statistics with oral cause and investigate their possible relationships with the work activities; dental examinations for labor purposes ${ }^{20}$.

The purpose of this study was to identify the factors involved in absenteeism in a steel industry in the city of São José dos Campos, SP, Brazil.

\section{Material and methods}

\section{Study Area}

The study was carried out in a steel industry in the city of São José dos Campos, São Paulo state. Occupying over 1,200 square meters, the unit has an installed production capacity of 7,200 tons per year. This industry operates in the manufacture of screens, trusses and columns, among others, used in construction, from buildings and roadways to small hydroelectric power stations. In 2010 the industry had 570 employees, with a working period of twenty-two days per month.

\section{Study Design}

This is a cross-sectional study, descriptive and quantitative, addressing absenteeism and prevalence of causes of absenteeism in the steel industry, between January 2005 and December 2008

\section{Data Collection}

The research was carried out from search in the digital file of the medical sector of the industry, data on medical and dental certificates issued in the study period. Medical records are filed at the Health Department of the steel industry.

Data were collected on the following variables:

- With respect to the worker: sex (male and female), function

- With regard to absenteeism:

* Duration of absenteeism or lost days (days)

* Causes of absenteeism (International Classification of Diseases - 10th Revision, ICD-1021)

* Certificate type: medical and dental

* Work sector, according to the Large Groups (LG) of Brazilian Classification of Occupations $-2002^{22}$ (Chart 1)

* Working periods: Shift 1: Monday to Friday $6 \mathrm{am}-2 \mathrm{pm}$ and Saturday 6 am $-1 \mathrm{pm}$; Shift 2: Monday to Friday $2 \mathrm{pm}-10$ $\mathrm{pm}$ and Saturday $1 \mathrm{pm}-8 \mathrm{pm}$, Shift 3: Monday to Friday $10 \mathrm{pm}$ -6 am and Sunday $11 \mathrm{pm}-6$ am; Shift 4: Monday to Friday 8 am to noon and $1 \mathrm{pm}$ to $5 \mathrm{pm}$, Shift 5 (workers of 3-Shift changes), Shift 6 (workers of 2 -Shift changes), $1 / 2$ period, Trainees.

Chart 1 - Brazilian Classification of Occupations in Large Groups / Titles according to the level of competence ${ }^{22}$.

\begin{tabular}{lll}
\hline & $\begin{array}{l}\text { Brazilian Classification of Occupations (BCO-2002) in } \\
\text { Large Groups (LG) }\end{array}$ & $\begin{array}{l}\text { Level of } \\
\text { Competence }\end{array}$ \\
\hline 0 & Armed Forces, Police and Military Firefighters & Undefined \\
1 & $\begin{array}{l}\text { Members of public authorities, managers of public } \\
\text { interest organizations and companies and managers }\end{array}$ & Undefined \\
2 & $\begin{array}{l}\text { Professionals of the sciences and the arts } \\
3\end{array}$ & Middle level technicians \\
4 & Administrative service workers & 3 \\
5 & $\begin{array}{l}\text { Service workers, sellers of shops in shops and } \\
\text { markets }\end{array}$ & 2 \\
6 & $\begin{array}{l}\text { Agricultural, forestry, hunting and fishing workers } \\
7\end{array}$ & $\begin{array}{l}\text { Workers in the production of industrial goods and } \\
\text { services (crafts) }\end{array}$ \\
\hline & $\begin{array}{l}\text { Workers in the production of industrial goods and } \\
\text { services (machines) }\end{array}$ & 2 \\
9 & Maintenance and repair workers & 2 \\
\hline
\end{tabular}




\section{Data Analysis}

The study adopted the concept of medical cause of absenteeism from the International Labor Organization ${ }^{23}$, i.e., "the period of absence from work which is accepted as attributable to an inability of the individual, except for the one derived from normal pregnancy or prison." It is understood by the uninterrupted period of absence from work, told from the very beginning, regardless of its duration. We used the recommendations of the Subcommittee on Absenteeism of the International Society for Occupational Health, addressing the indices of frequency, severity, percentage rate of absenteeism, average length of absences, as indicators of absenteeism, represented by the formulas below: ${ }^{23}$.

- Frequency index $=$ Total number of cases/number of employees

- Severity index $=$ Total lost days/number of workers

- Percentage rate of absenteeism $=$ Total lost days $\mathrm{x} 100 /$ Total days worked $\mathrm{x}$ number of workers

- Average length of absences $=$ Total lost days/Total number of cases

The prevalence of abdsences was addressed by the International Classification of Diseases - 10th Revision (ICD-10) and the specific highlights were the greatest highlights in terms of lost days and number of occurrences, also distributed by sex and function.

The dependent variables were the number of lost days and the number of events. Short-term offsets were those of up to five days, medium duration between six and fifteen days and large deviations of more than sixteen days.

As independent variables, sex, function and medical nature (ICD-10) of the condition were used.

For the statistical analysis, the statistical package SSP was used. ANOVA and the Student's t-test were used to verify the differences between the means of the number of lost days and the number of events, adopting a significance level of 5\% $(p<0.05)$. The results were expressed by tables, in frequency and proportions.

\section{Ethical Considerations}

This research was approved by the Ethics Committee of the Dental School of Piracicaba, UNICAMP, under Approval Protocol number 051/2009.

\section{Results}

A total of 570 workers were included in the final analysis. Among the 570 workers in the steel industry, 63\% $(n=354)$ presented absenteeism and $37 \%(\mathrm{n}=216)$ did not present absenteeism, from January 2005 to December 2008, in a total of 1245 certificates.

It was observed that $97 \%(n=1209)$ of the presented certificates were for male and $3 \%(n=36)$ were for female workers.

There was a higher percentage of medical certificates (97\%; $\mathrm{n}=1204)$, in relation to the dental certificates $(3 \% ; \mathrm{n}=41)$.

In the steel industry, since there are several functions, it was necessary to group them according to the Brazilian Classification of Occupations - 2002, in large groups (LG)22. The large groups LG- 6 and LG- 8 were not part of this research, since they do not apply to the studied field (Table 1).

Table 1 - Distribution of cases of absenteeism in relation to the Large Groups of the Brazilian Classification of Occupations (BCO-2002).

\begin{tabular}{ll}
\hline Large Groups & Cases of absenteeism \\
\hline LG-1 & $0.41 \%(n=5)$ \\
LG-2 & $3.05 \%(n=38)$ \\
LG-3 & $12.85 \%(n=160)$ \\
LG-4 & $8.51 \%(n=106)$ \\
LG-5 & $0.88 \%(n=11)$ \\
LG-7 & $62.09 \%(n=773)$ \\
LG-9 & $10.28 \%(n=128)$ \\
Others & $1.93 \%(n=24)$ \\
TOTAL & $100 \%(n=1245)$ \\
\hline
\end{tabular}

Among the 773 workers' certificates classified in LG-7, the industrial machine operators presented the highest percentage $(68.3 \%)$, followed by production auxiliaries $(21.35 \%)$ and bridge operators $5.82 \%$ (Table 2).

Table 2 - Distribution of cases of absenteeism in relation to the Large Group (LG) 7 of the Brazilian Classification of Occupations (BCO-2002).

\begin{tabular}{ll}
\hline Functions of the LG-7 & Cases of absenteeism \\
\hline Production auxiliaries & $21.35 \%(n=165)$ \\
Production Manager & $0.13 \%(n=1)$ \\
Thermal Treatment Forge & $0.52 \%(n=4)$ \\
Forklift Operator & $2.07 \%(n=16)$ \\
Industrial machine operators & $68.3 \%(n=528)$ \\
Machine Operator & $0.39 \%(n=3)$ \\
Bridge operators & $5.82 \%(n=45)$ \\
Financial Accountant & $1.03 \%(n=8)$ \\
Welder & $0.39 \%(n=3)$ \\
Total & $100 \%(n=773)$ \\
\hline
\end{tabular}

The workers were divided into 8 different working periods, separated according to the denominations used by the forgery. Higher absenteeism prevalence as found in the labor Shift 4 with $44.42 \%(n=553)$, Shift 5 with $27.07 \%(n=337)$ and Shift 6 with $15.18 \%(\mathrm{n}=189)$ (Table 3$)$.

Table 3 - Distribution of absenteeism cases related with working periods.

\begin{tabular}{ll}
\hline Working periods & Cases of absenteeism \\
\hline Shift 1 & $5.62 \%(n=70)$ \\
Shift 2 & $3.21 \%(n=40)$ \\
Shift 3 & $3.05 \%(n=38)$ \\
Shift 4 & $44.42 \%(n=553)$ \\
Shift 5 & $27.07 \%(n=337)$ \\
Shift 6 & $15.18 \%(n=189)$ \\
$1 / 2$ period & $0.25 \%(n=3)$ \\
Trainees & $1.2 \%(n=15)$ \\
Total & $100 \%(n=1245)$ \\
\hline
\end{tabular}


In the study of 1245 absences in relation to ICD-10, the highest incidence was of musculoskeletal and connective tissue diseases (M00-M99) $(\mathrm{n}=230)$; diseases of the respiratory system (J00-J99) $(\mathrm{n}=213)$; injuries, poisoning and some other consequences of external causes (S00-T98) $(\mathrm{n}=140)$; diseases of the digestive tract $(\mathrm{K} 00-\mathrm{K} 93)$ $(n=130)$, infectious and parasitic diseases $(n=102)$ (Table 4).

Among the 130 occurrences of the digestive system tract diseases $(\mathrm{K} 00-\mathrm{K} 93), 31 \%(\mathrm{n}=40)$ represented diseases of the oral cavity, salivary glands and jaws (K00-K14).

Out of the 140 occurrences of lesions, poisoning and some other consequences of external causes, $4 \%(n=6)$ were by head trauma $(\mathrm{S} 00-\mathrm{S} 09)$ and $1 \%(\mathrm{n}=1)$ were by dental fracture $(\mathrm{S} 02.5)$.

The total number of lost days in the four study years was 3,187. The highest percentages were: with LG-7 accounting for $72.95 \%(n=2,325), L G-3$ for $10.98 \%(n=350), L G-9$ for $7.37 \%$ $(n=235)$. LG-1 and LG-5 had low percentage of lost days (Table 5).

Table 4 - Distribution of the number of cases of absenteeism according to the International Classification of Diseases (ICD-10), sex (male and female) and LG (BCO-2002).

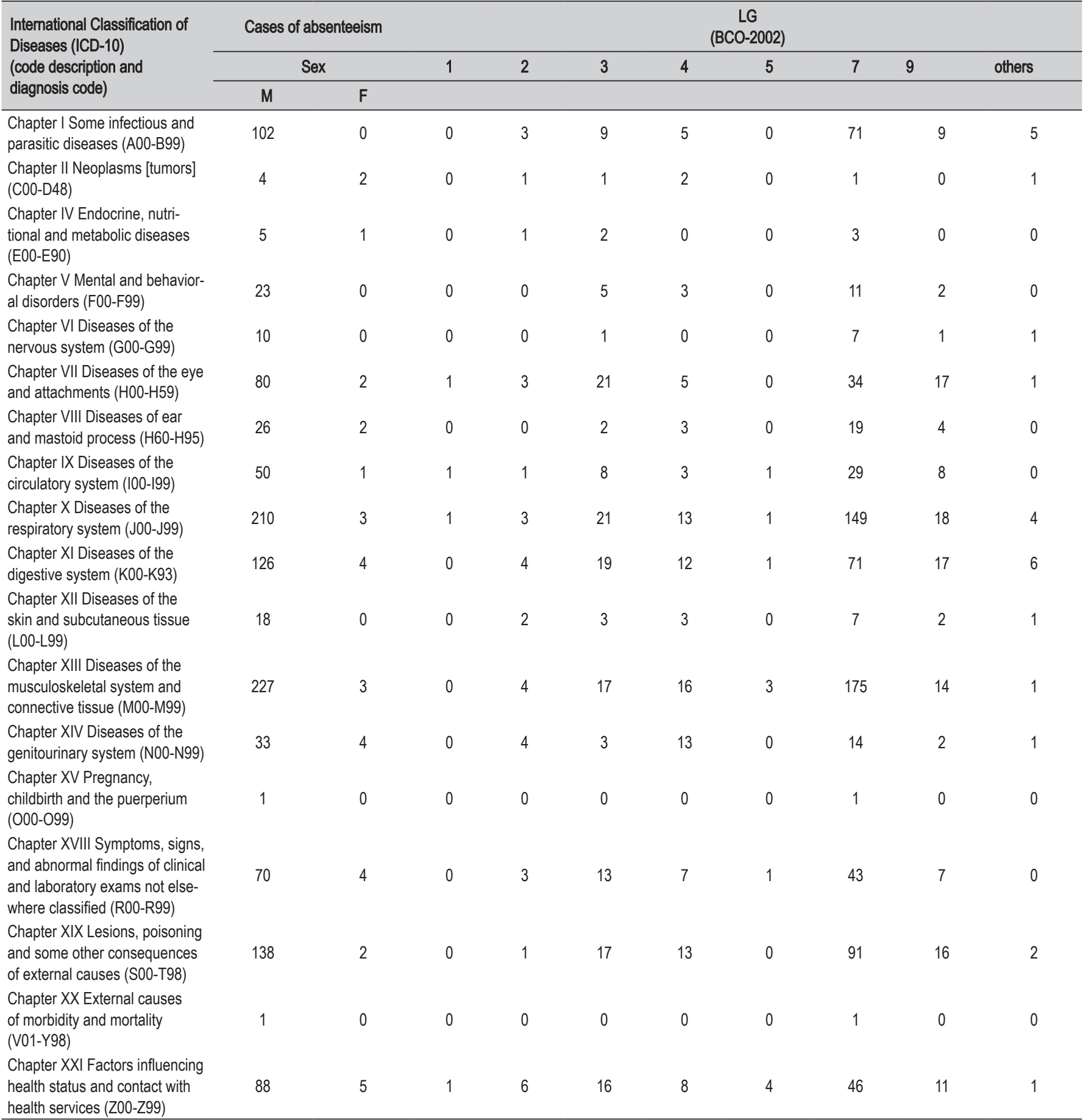


Table 5 - Distribution of lost days in relation to the Large Groups, BCO-2002 in the four study years.

\begin{tabular}{cc}
\hline LG (BCO-2002) & Lost days \\
\hline LG-1 & $0.29 \%(\mathrm{n}=9)$ \\
LG-2 & $1.91 \%(\mathrm{n}=61)$ \\
LG-3 & $10.98 \%(\mathrm{n}=350)$ \\
LG-4 & $5.27 \%(\mathrm{n}=168)$ \\
LG-5 & $0.29 \%(\mathrm{n}=9)$ \\
LG-7 & $7.37 \%(\mathrm{n}=235)$ \\
LG-9 & $72.95 \%(\mathrm{n}=2325)$ \\
Others & $0.94 \%(\mathrm{n}=30)$ \\
TOTAL & $100 \%(\mathrm{n}=3187)$ \\
\hline
\end{tabular}

Following the recommendations of the Subcommittee on Absenteeism of the International Society of Occupational Health $^{23}$, addressing the indices of frequency, severity, percentage rate of absenteeism, average length of absences, as indicators of absenteeism, were as follows:

- Frequency index $=2.1842$

- Severity index $=5.5912$

- Percentage rate of absenteeism $=2.5598$

- Average duration of absences $=0.58 \%$

The prevalence of withdrawals was addressed by the International Classification of Diseases (ICD-10) grouping, and by specific morbidities of the major highlights in terms of lost days (groups V and XIII) and number of occurrences (groups XIII, X, XIX and XI), also distributed by sex and function (Tables 4 and 6)

Table 6 - Distribution of the number of absentee days in relation to the number of cases.

\begin{tabular}{lcc}
\hline number of days & number of cases & average $(\%)$ \\
\hline $1-5\left(^{*}\right)$ & 203 & 1.9556 \\
$6-15$ & 86 & 9.7906 \\
$\geq 16$ & 65 & 29.969 \\
\hline$\left(^{*}\right)$ We included the 32 cases that an error in the system recorded as 0 days, but they \\
were $1 / 2$ period absences.
\end{tabular}

The differences between the means of the number of days of withdrawal and the number of events were performed by analysis of variance (ANOVA) obtaining $F=36.41(p=0.00000003)$ and the Student $t$ test equal to 1.479 with an error margin of $0.5 \%$.

Figure 1 shows the distribution of lost days in relation to number of cases in the studied four years.

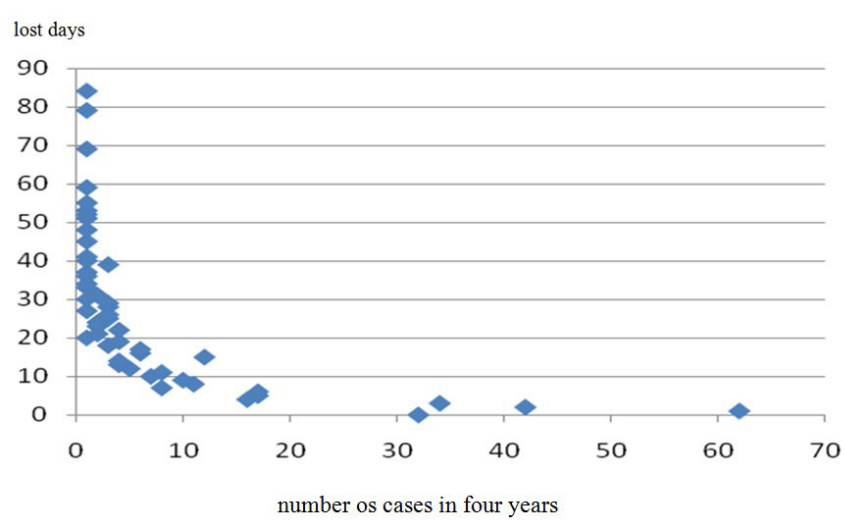

Fig.1. Distribution of lost days in relation to number of cases in the four study years.

\section{Discussion}

Prevalence of certificates of male workers (97\%) aree with the results found by Biswas et al. (2014) ${ }^{2}$, Höflmann and Blank (2008) ${ }^{13}$, Manjunatha et al. $(2011)^{24}$, Lacerda et al. $(2008)^{25}$, Teles $(2005)^{26}$. However, Perez et al. (2006) $)^{15}$ and Danatro $(1997)^{27}$ found a larger number of absences.

There was a higher percentage of medical certificates (97\%) compared with Höfelmann and Blank (2008) $)^{13}$, Danatro $(1997)^{27}$, Paulo (2007) $)^{28}$, Ito (2007) ${ }^{29}$, Martins et al. (2005) $)^{30}$, Panzer (2004) ${ }^{31}$, Mesa and Kaempffer (2004) $)^{32}$, Tomasini $(2001)^{33}$, Rocha $(1981)^{34}$.

Of the 773 attestations of workers classified as LG-7, the industrial machine operators presented the highest percentage $(68.3 \%)$, similar to the ones found in the studies of Biswas et al. $(2014)^{2}$, Manjunatha et al. (2011) 24; Panzer (2004) $)^{31}$, Mesa and Kaempffer (2004) ${ }^{32}$, Tomasini $(2001)^{33}$.

In relation to ICD-10, among 1245 absences, the highest incidence was of musculoskeletal and connective tissue diseases (M00-M99), which corroborates the studies by Biswas et al. (2014)2, Manjunatha et al. (2011) ${ }^{24}$; Panzer (2004) ${ }^{31}$, Mesa and Kaempffer $(2004)^{32}$, Danatro $(1997)^{27}$. For Gillies $(1994)^{35}$, it were respiratory diseases, digestive disorders, circulatory problems, gynecological disorders and pathological neuroses. Studies by Guo et al. $(2015)^{36}$, Wada et al. $(2013)^{37}$ point out that the highest amount is of mental and behavioral disorders.

Over the years, interest in the subject has been expanding and new research has been carried out, but there are still few nationally published studies related to the buccal health of the worker in the industries ${ }^{13,15,25,28-30,34,38-40}$. It is expected that the specialists in Occupational Dentistry will carry out new studies demonstrating to the employers the benefit of having a worker with good oral health, regardless of being or not a a company's obligation.

The results of our study were similar to Rocha's ${ }^{34}$ study regarding the lack of odontological reasons for the one that contributed least to absenteeism, and medical causes were the most common. Rocha ${ }^{34}$ developed a study in a metallurgic industry in Canoas, Rio Grande do Sul, Brazil, whose objective was to determine the level of absenteeism from work for medical reasons by analyzing medical service data and questionnaires applied to workers, the level of absenteeism due to work accident, the degree of influence of dental causes in absenteeism (all in relation to the variables age, sex, employee's role in the company and length of service) and the level of perception of the workers regarding oral health and the dental service of the industry. He concluded that the lack of dental care was the one which contributed the least to absenteeism, which was overcome by work-related accidents and medical causes, which were the most common.

The results of our study were similar to Martins et al. ${ }^{30}$, where absences due to dental reasons had little weight on the total number of absences due to illness. Martins et al. ${ }^{30}$ studied absenteeism for dental and medical reasons, in the public (in the municipality of Araçatuba, SP, Brazil) and private (acrylic manufacture) services, from January to June 2002. They found that: absence due to dental reasons had little weight on the total number of absences due to illness, in addition to causing a shorter period of absence. The variables age, sex, function and employment regime influenced the absenteeism at work. 
Paulo $^{28}$ studied dental absenteeism in a metallurgical industry in the region of Contagem, MG, Brazil, in which he performed a survey of absences for health leave registered during four months. He collected data from all medical and dental certificates from June to September 2006. He found that medical certificates were 99\%, while dental certificates presented $1 \%$. Our study found that medical certificates were $97 \%$.

Höfelmann and Blank ${ }^{13}$ studied 482 workers from a metalwork industry in Santa Catarina, Brazil, in order to identify the factors that confounded the association between chronic diseases and/or symptoms and self-assessment of health among workers. Using self-administered questionnaires and anthropometric measures, hierarchical models of multiple logistic regression with a response rate of $98.6 \%(n=475)$ were adjusted. There were $84.8 \%$ in the male sex, $79.4 \%$ in the productive sector. The most common complaint was back pain and association between chronic diseases and health self-evaluation presented an odds ratio of 7.3 (95\% CI: 3.7; 14.5). With statistical modeling, psychosocial (-25.59\%), socioeconomic $(-9.29 \%)$ and occupational $(10.54 \%)$ variables were identified as confounding factors between the outcome and chronic diseases and/ or symptoms. They concluded that the way in which the diseases and/ or symptoms act in the health self-evaluation among workers goes beyond the physical aspects. Our study found the highest percentage $(68.3 \%)$ in the industrial machine operators.

Danatr ${ }^{27}$ conducted a survey of data from medical certificates issued between July 1, 1994 and June 30, 1995 in a public institution with 1,474 employees (594 in the administrative sector), in the city of Montevideo, Uruguay. 1,604 certificates had medical causes and 40 non-medical causes. The 1,604 certificates of medical cause generated 10,085 days of absence; the majority of the certificates were 1 day; the most representative diseases of the study were respiratory causes, musculoskeletal and connective tissue disorders, presence of risk factors, contact with health services and digestive diseases. Our study found the distribution of lost days in relation to number of cases in the four years study, the majority was between 0 and 10 lost days.

It was concluded that:

- Most certificates were for males (97\%), medical (97\%), LG-7 (62\%), industrial machinery operators (68\%) and Shift $04(44.43 \%)$;

- Total duration of the absences was 3,187 days. The main causes were osteomuscular and connective tissue diseases $(18.48 \%)$, respiratory diseases $(17.11 \%)$, lesions, poisoning and some other consequences of external causes (11.24\%), diseases of the digestive system (11.24\%);

- The greatest amount of lost days was in groups $\mathrm{V}$ and $\mathrm{XIII}$ and the greatest number of occurrences was in groups XIII, X, XIX and XI;

- The differences between the means of the number of lost days and the number of events were $\mathrm{F}=36.41(\mathrm{p}=$ 0.00000003 ) and the Student $t$ test was equal to 1.479 with a margin of error of $0.5 \%$;

- There is a suggestion of under-reporting regarding the origin of dental absenteeism (41 events) in the study period;

- Further studies in this field are required.

\section{References}

1. Barros G. [The development of the Brazilian steel industry between 1900 and 1940: Growth and import substitution]. Estud Econ. 2015 JanMar;45(1):153-83. Available from: http://www.scielo.br/pdf/ee/v45n1/01014161-ee-45-01-0153.pdf. Portuguese.

2. Biswas MJ, Koparkar AR, Joshi MP, Hajare ST, Kasturwar NB. A study of morbidity pattern among iron and steel workers from an industry in central India. Indian J Occup Environ Med. 2014 Sep-Dec;18(3):122-8. doi: 10.4103/0019-5278.146909.

3. Baroni G. [The influence of toothache]. Rev CIPA. 1996;17(202):40-51. Portuguese.

4. Schour I, Sarnat BG. Oral manifestation of occupational origin. JAMA. 1942;120:1197-207.

5. Macedo CG, Queluz DP. Quality of life and self-perceived oral health among workers from a furniture industry. Braz J Oral Sci. 2011 OctDec;10(4):226-32.

6. Macedo CG, Queluz DP. Medical and dental absenteeism in workers from a furniture industry in Itatiba, SP, Brazil. Braz J Oral Sci. 2010 OctDec;9(4):443-8.

7. Nardi A, Michel-Crosato E, Biazevic MGH, Crosato E, Pizzatto E, Queluz DP. Relationship between orofacial pain and absenteeism among workers in Southern Brazil. Braz J Oral Sci. 2009 Jan-Mar;8(1):50-4.

8. Lima JR. [Absenteeism for dental reasons: comparative analysis between employees of the municipality of São José dos Campos and insured persons of the National Institute of Social Security] 2001 [cited 2016 Mar]. Available from: http:www.odontologia.com.br/artigos.asp. Portuguese.

9. Queluz DP. Labour Dentistry: a new specialty in Dentistry. Braz J Oral Sci. 2005 Jul-Sep;4(14):766-72.

10. Probst TM. Safety and insecurity: Exploring the moderating effect of organizational safety climate. J Occup Health Psychol. 2004 Jan;9(1):3-10.

11. Ramazzini B. De morbis artificum diatriba [diseases of workers]. 1713. Am J Public Health. 2001 Sep;91(9):1380-2.

12. Rouquayrol MZ, Almeida NF. [Epidemiology and health]. 5. Ed. Rio de Janeiro: MEDSI; 1999. Portuguese.

13. Höfelmann DA, Blank N. Association between self-reported diseases and symptoms and self-rated health. Cad Saude Publica. 2008;24(5):983-92.

14. Andrade TB, Souza MGC, Simões MPC, Andrade FB. [Prevalence of absenteeism among public service workers]. Sci Med. 2008;18(4):166-71. Portuguese.

15. Peres SHCS, Peres AS, Oliveira FT, Adachi A, Silva AL, Morandini ACF, et al. [Absenteeism: a review of the literature on absenteeism related to dentistry]. Rev Odontol Araçatuba, 2006;27(2):96-100. Portuguese.

16. Yaedú RYF. [Epidemiological survey of oral lesions and their relationship to the profession, gender, age, biotype and origin of the patients attended at the stomatology clinic of the Faculty of Bauru - USP]. [dissertation]. Bauru: USP/ FO; 2005. Portuguese.

17. Rushton L, Betts B. Collection of data for occupational epidemiologic research - results from a survey of European industry. Scand J Work Environ Health. 2000 Aug;26(4):327-31.

18. Almeida TF, Vianna MIP. [The role of epidemiology in planning the worker's oral health actions]. Saude Soc. 2005;14(3):144-54. Portuguese.

19. Santos EJ, Queluz DP. Factors involved in dentistry absenteeism since the foundation of the Labor Court from 1986 to 2008. Braz J Oral Sci. 2012 Oct-Dec;11(4):492-504.

20. Federal Dentistry Council. [cited 2016 Mar]. Available from: http://www. cfo.org.br.

21. World Hearth Organization. International Classification of Diseases. [cited 2016 Mar]. Available from: www.who.int/whosis/icd10.

22. Ministry of Labor and Employment. [cited 2016 Mar]. Available from: http:// www.mtecbo.gov.br/cbosite/pages/informacoesGerais.jsf.

23. OIT. Oficina Internacional del Trabajo. Enciclopedia de Salud. Seguridad e Higiene en el Trabajo. Madrid: Centro de Publicaciones del Ministerio 
de Trabajo y Seguridad Social; 1991.

24. Manjunatha R, Kiran D, Thankappan KR. Sickness Absenteeism, morbidity and workplace injuries among iron and steel workers - A Cross Sectional Study from Karnataka, Southern India. Australas Med J. 2011;4(3):144-7. doi: 10.4066/AMJ.2011.576

25. Lacerda, JT, Traebert J, Zambenedetti ML. [Orofacial pain and absenteeism in workers of the metallurgical and mechanical industry]. Saude Soc. 2008;17(4):182-91. Portuguese.

26. Teles MP. [Oral health conditions in workers of a metallurgical industry in the metropolitan region of Salvador ] [dissertation]. Salvador; UFB/ FOS; 2005. Portuguese.

27. Danatro $D$. Ausentismo laboral de causa medica en una instituición pública de Montevideo: 1994-1995. Rev Med Uruguay. 1997;13(2):101-9.

28. Paulo VC. [Absenteeism due to odontological reasons withing a metallurgical industry in the region of Contagem-MG]. ABO-MG. 2007;59 p. Portuguese.

29. Ito SC. [Working conditions and dental absenteeism in a Brazilian cold store: a contribution to occupational health management] [dissertation]; São Paulo; Centro Universitário SENAC; 2007. Portuguese.

30. Martins RJ, Garbin CAS, Garbin AJÍ, Moimaz SAS. [Absenteeism for dental and medical reasons in public and private services]. Rev Bras Saude Ocup. 2005;30(111):9-15. Portuguese.

31. Panzer RA. [Correlation between overtime and work accidents, complaints of musculoskeletal pain, absenteeism and productivity in a metallurgical company in Porto Alegre, in the years 2002 and 2003] [dissertation] Porto Alegre: UFRS; 2004. Portuguese.

32. Mesa FRM, Kaempffer AMR. 30 Años de estudio sobre ausentismo laboral en Chile: una perspectiva por tipos de empresas. Rev Med Chile,
2004;132(9):1100-8.

33. Tomasini A. [Development and application of ergonomic management model for a metallurgical industry company] [dissertation] Porto Alegre: UFRS; 2001. Portuguese.

34. Rocha JAD. [Absenteeism to work by disease and the implication of oral health as one of its factors in a metallurgical industry in the city of Canoas] [dissertation]. Natal: Universidade Federal do Rio Grande do Norte; 1981. Portuguese.

35. Gillies DA. Gestión en enfermaria. Barcelona: Masson-Salvat; 1994. p.321-7.

36. Guo H, Guo H, Yang Y, Sun B. Internal and External Factors Related to Burnout among Iron and Steel Workers: A Cross-Sectional Study in Anshan, China. PLoS One. 2015;10(11): e0143159. doi: 10.1371/journal. pone.0143159

37. Wada K, Arakida M, Watanabe R, Negishi M, Sato J, Tsutsumi A. The Economic Impact of Loss of Performance Due to Absenteeism and Presenteeism Caused by Depressive Symptoms and Comorbid Health Conditions among Japanese Workers. Ind Health. 2013 Sep;51(5):482-9.

38. Pinto VG, Lima MOP. [Epidemiological study of oral health in industrial workers. Brazil; 2002-2003] [cited 2016 Mar]. Available from: http://www. sesi.org.br/Programas/saude_bucal/saude_bucal/pdf/Estudo_Saude_ Bucal_COMPLETO.pdf. Portuguese.

39. Lido YJVM. [Analysis of dental care provided by companies in the metropolitan region of Campinas] [dissertation]. Piracicaba: FOP/ UNICAMP; 2008. Portuguese.

40. Teles MP, Almeida TF, Cangussu MCT, Vianna MIP. [Occupational exposure and oral health of the worker]. Rev Cienc Med Biol. 2006;5(1):4854. Portuguese. 